\title{
A study on the design of bamboo grinding machine
}

\author{
Nguyen Hoang Hiep ${ }^{1}$, Vo Tuyen ${ }^{2}$, Le Khanh Dien ${ }^{1, *}$, Nguyen Tan Hung ${ }^{3}$
}

${ }^{1}$ DCSELAB, Ho Chi Minh City

University of Technology, VNUHCM,

Vietnam

${ }^{2}$ Ho Chi Minh City University of Food Industry (HUFI), Vietnam

${ }^{3}$ Cao Thang Technical College, Vietnam

Correspondence

Le Khanh Dien, DCSELAB, Ho Chi Minh City University of Technology, VNUHCM, Vietnam

Email: Ikdien@dcselab.edu.vn

History

- Received: 15-10-2018

- Accepted: 02-1-2019

- Published: 31-12-2019

DOI : 10.32508/stdjet.v3iSI1.734

\section{Check for updates}

\section{Copyright}

(.) VNU-HCM Press. This is an openaccess article distributed under the terms of the Creative Commons Attribution 4.0 International license.

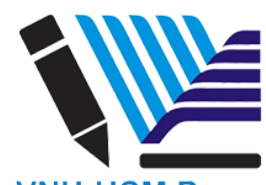

VNU-HCM Press

\begin{abstract}
Bamboo is a sustainable and environmental friendly material that has the potential to improve the global decline of natural resources. Bamboo is one of the popular flora in Southeast of Asia, it is also traditional plants that grow abundantly in Vietnamese villages from north to south. Its ability can replace some kinds of wood in decoration and household goods. Bamboo grow up rapidly and can be harvested within 3 to 5 years of planting, in the meanwhile the harvesting time of other hardwood trees must be from 8 to 10 years or longer. The inherent characteristics of bamboo is lighter than other wood materials and has a value in social and environmental benefits. Its advances in manufacturing technology have created high value products such as bamboo flooring and bamboo furniture that can substitute for wood flooring and wood furniture. According to the biology studies, the bamboo has the characteristics that can replace the natural wood, but the direction of development from the stage of cultivation to the stage of finished products has not been exploited thoroughly. The production of bamboo plywood will become a great potential for the bamboo plywood industry in Vietnam. Generally, the fabrication of bamboo plywood depends on the following processes such as cutting, grinding to powder or pulp, drying and pressing processes. In cutting and grinding processes, the trivial remains of bamboo after use, shoots... can be chopped and grinded to powder that is dried and pressed into bamboo plywood by specialized machine similar to the production artificial wood particleboard (PB). The aim of this paper is a representation of a design, a computing the structure of a version of bamboo grinding machine that is sustainable, responds to technical requirements and protect of environment. The result of the design was applied for manufacture a typical bamboo machine in CAD-CAM workshop of DCSELAB in the framework of a project between DCSELAB and PhuAn Village Corporation that has evaluated with satisfaction the realistic proof of the design. The machine has been in the session of initial testing and exploitation.
\end{abstract}

Key words: Bamboo plywood, Bamboo powder, Grinding machine

\section{INTRODUCTION}

Bamboo is a sustainable and environmentally friendly material that has the potential to improve the global decline of natural resources, particularly its ability of replacing the natural wood. From planting to harvesting there are only 3 to 5 years in comparison of the hard tree, it must be from 10 to 20 years to mature for harvesting. The inherent characteristics of bamboo in daily life, decoration and construction confirm its valuable position in consumer market such as: leaves for covering some kinds of traditional cakes, stem for column of thatched cottage, bamboo mat, bamboo plywood... Abundance and cheap price are the bamboo specificity that it can substitute for wood in flooring furniture with social and environmental benefits. Currently, according to the biology studies, the bamboo has the characteristics that can replace the natural wood, but the direction of development from the stage of cultivation to the stage of finished products has not been exploited and applied logically in our country.
The closure and restrictive exploitation of forests in many countries around the world are an opportunity for the great demand of bamboo, but it is also a big challenge for businesses in developing of quality bamboo in Vietnam ${ }^{1}$.

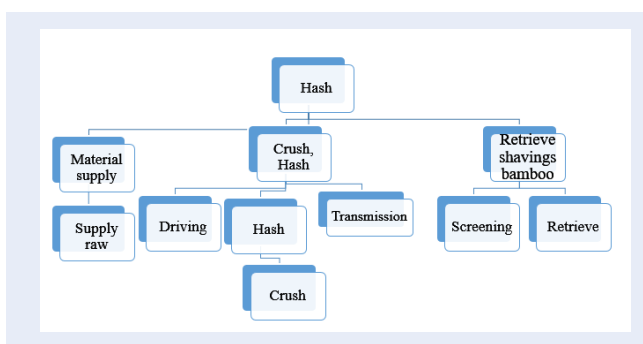

Figure 1: Schema of production of bamboo powder in functional modules.

With abundant bamboo resources, the production of bamboo plywood becomes a great potential for the domestic bamboo plywood industry. The first process 


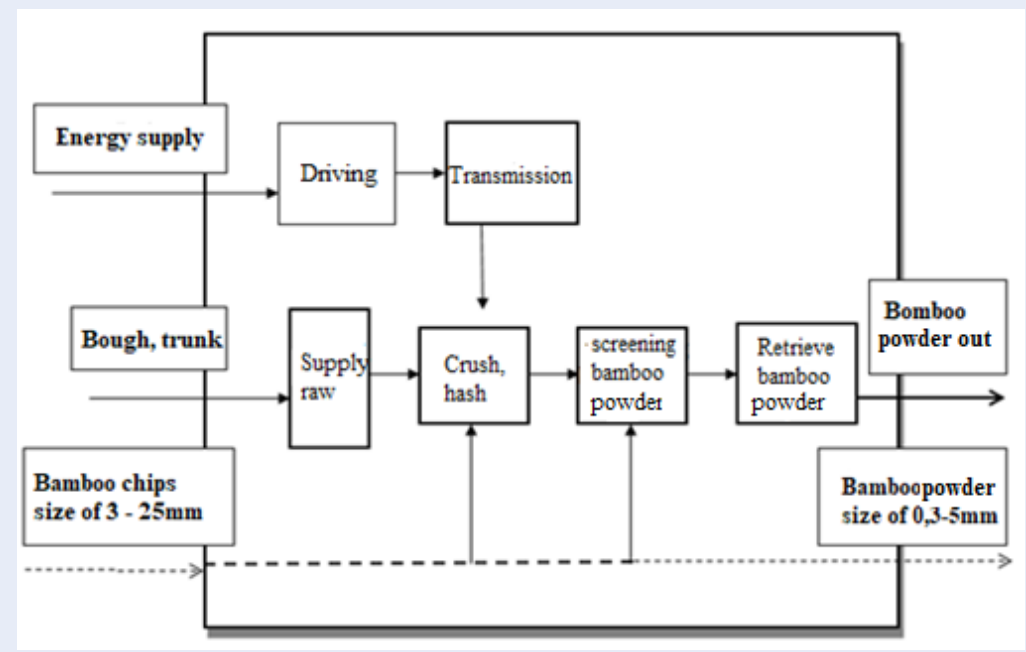

Figure 2: Functional map of bamboo crusher.

after bamboo harvesting is grinding bamboo to pulp or powder. All kind of bamboo waste such as bamboo shoots, bad stems, roots can be raw material for the process ${ }^{2}$.

In the production process of bamboo plywood powder, the bamboo-grinding machine plays a very important role in the production of bamboo powder, the basic material for plywood. The schema of grinding process is illustrated tin Figure $\mathbf{1}^{3}$.

\section{METHODOLOGY OF RESEARCH - STRUCTURAL DESIGN ${ }^{4}$}

Functional analysis of bamboo grinding machines is illustrated in diagram in Figure 2. Figure 3 represents the structure of the designed bamboo-grinding machine.

Generally, a bamboo grinding machines consists of the following main components:

- Electric motors

- Mechanical transmission

- Feeder (feed hopper)

- Grinding spindle of the machine (disk of cutters, hammers...)

- Discharge unit

\section{RESULTS AND DISCUSSION - COMPUTING STRENGTH MATERIAL}

\section{a. Initial data}

- Productivity $200 \mathrm{Kg} / \mathrm{h}$.

- Main raw materials: bamboo shoots, stem, roots.

- Size of raw materials: $20-100 \mathrm{~mm}$.

- Size of bamboo powder after grinding process: 0.5

$-3 \mathrm{~mm}$.
- Specific density of bamboo: $800 \mathrm{Kg} / \mathrm{m} 3$.

- Average powder moisture 12-14\%.

The general structure of the machine is as shown in Figure 4.

Computing of the bamboo grinding machine

\section{b. Cutting parts:}

According to the principle of slice pieces ${ }^{5}$, the 4 cutters are freely mounted on the disk via a hinge that allows the cutter a free rotation of an angle $\pm 60^{\circ}$ around its radial position that formed in advance by the centrifuge force in operation.

Cutting angle $\alpha$ of the cutter blade is selected about 12 $-15^{\circ}$ because of cutting of tough and medium wood materials.

Cutting speed is selected in a range of $30-60 \mathrm{~m} / \mathrm{s}$ )

The power of cutting is determined by the formula ${ }^{5}$ : $\mathrm{N}_{1}=\mathrm{k} \times \mathrm{b} \times \mathrm{h} \times \mathrm{v} / 10^{2}$

Herein: b: Cutting thickness is about $0.5 \mathrm{~mm}$;

h: thickness of the raw bamboo material is $25 \div$ $50 \mathrm{~mm}$;

$\mathrm{k}$ : specific deflection coefficient is 1 ;

$\mathrm{v}$ - velocity of the hash, $\mathrm{v}=30 \mathrm{~m} / \mathrm{s}$.

We have : $\mathrm{N}_{1}=\mathrm{k} \times \mathrm{b} \times \mathrm{h} \times \mathrm{v} / 10^{2}=1 \times 0.5 \times 50 \times$ $30 / 10^{2}=7.5 \mathrm{~kW}$

The revolution on the spindle is calculated according to the formula : $\omega=\frac{V_{b}}{R}$;

Herein $: \mathrm{v}_{b}=30 \mathrm{~m} / \mathrm{s}$

Radius of cutter point on plate $\mathrm{R}=100 \mathrm{~mm}=0.1 \mathrm{~m}$ The revolution of the tool shaft is:

$n=30 \times \omega / \pi=30 \times V_{b} /(\pi \times R)=30 \times 30 /(\pi \times$ $0.1)=2864 \mathrm{rpm}$. 


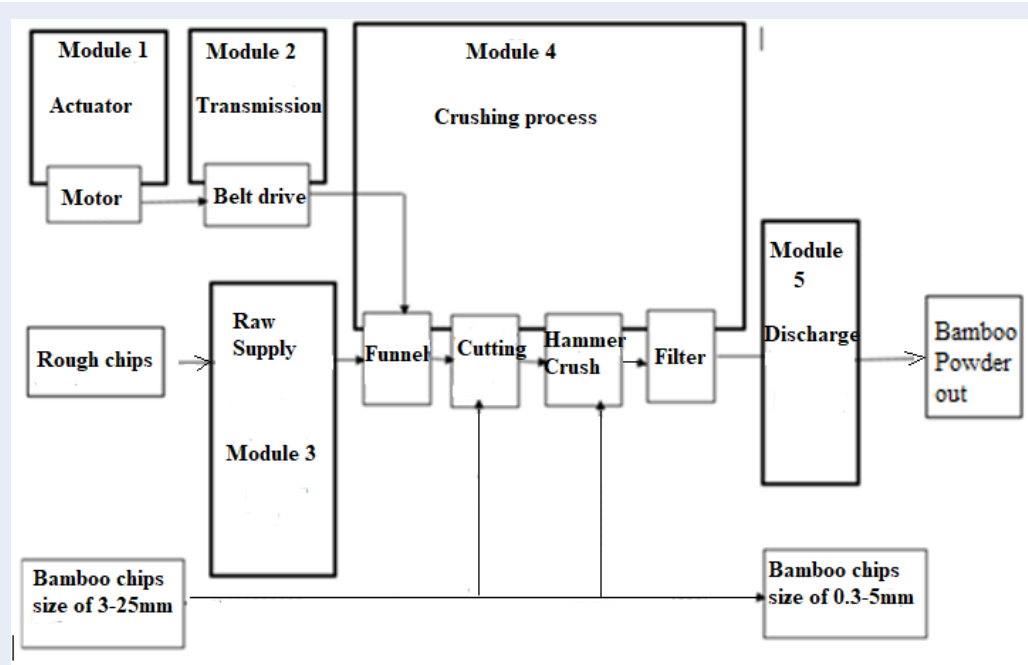

Figure 3: Structural diagram of bamboo crush machine.

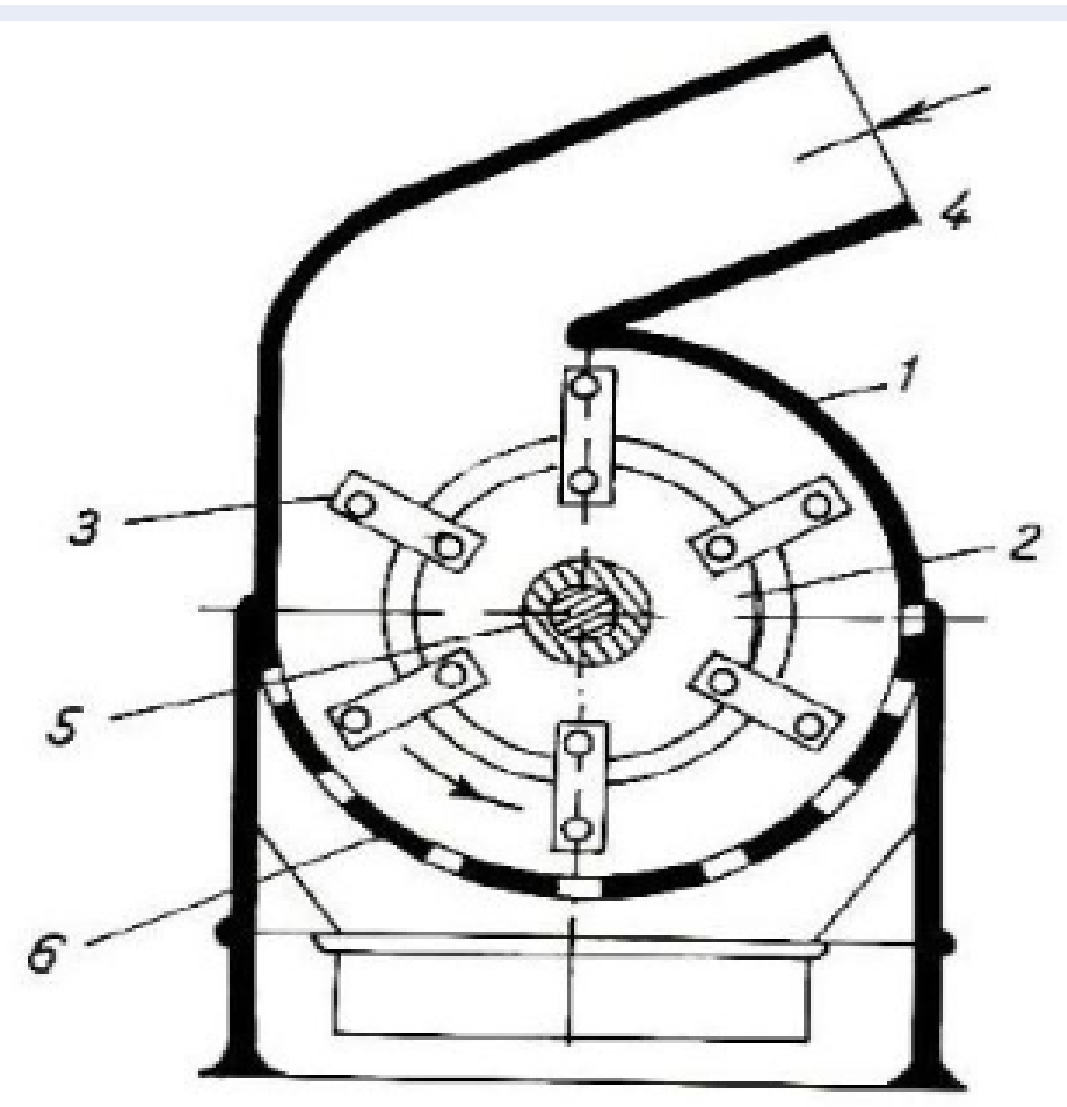

Figure 4: Structure of the designed bamboo-grinding machine ${ }^{6}$ 1-Machine cover; 2 -Cutter Frame; 3-Cutters; 4-Material input; 5-Shaft; 6-Circular Filter screen 
Selected transmission ratio for the drive system is 1 , we have the number of motor rotation

$\mathrm{n}=2864 \mathrm{rpm}$

\section{Grinding parts :}

Because of the product size of $0.5-3 \mathrm{~mm}$ with the impact velocity of the machine is about $25-60 \mathrm{~m} / \mathrm{s}$, combined with the condition of cutting speed, the cutting speed...The selected weight of each cutter is about 30 $50 \mathrm{~N}$.

Selective shape of cutter is triangle with 3-4 rows of cutters.

The power of the grinding machine is determined by the formula:

$N_{2}=0.15 \times D^{2} \times L \times n \times i=0.15 \times 0.2^{2} \times 0.1 \times$

$2864 \times 3=5.2 \mathrm{~kW}$

Herein: D- rotor diameter, $D=60 \times v /(\pi \times n)=$ $60 \times 30 /(\pi \times 2864)=0.2 m$.

Length of rotor $\mathrm{L}=0.1 \mathrm{~m}$.

Revolution of shaft $\mathrm{n}=2864 \mathrm{rpm}$.

Number of cutters rows $i=3$.

Motor and transmission selection:

The belt feeder is used to transfer power from the engine to the grinder. With the transmission rate is 1 , total performance coefficient is $\eta=\eta 1 . \eta 2=0.99 \times$ $0.96=0.95 ; \eta 1 \times \eta 2-$ efficiency of the drive and belt transmission $\mathrm{P}_{c t}=\mathrm{P}_{1}+\mathrm{P}_{2}=7.5+5.2=12.7 \mathrm{~kW}$; The 3K200M8 electric motor that has parameters of motor power of $15 \mathrm{~kW}$ and revolutions of $2800 \mathrm{rpm}$ is selected. The grinding module include motor and belt transmission is displayed in Figure 5.

\section{CONCLUSION}

The research performed an efficient design process to produce bamboo-grinding machine that meet the technical requirements. Experimental results show that complete grinding bamboo machine responds all the technical requirements of the production system of bamboo plywood powder.

\section{ACKNOWLEDGEMENT}

This research is supported by DCSELAB and funded by Vietnam National University Ho Chi Minh City (VNUHCM) under grant number TX2018-20b-01 and GEN2016-48-02. We appreciate highly the great support of DCSELAB which allowed and gave us a lot of facilities to perform the experiments and this paper.

\section{CONFLICT OF INTEREST}

There is no conflict of interest.

\section{AUTHORS' CONTRIBUTIONS}

The authors declare that all authors discussed the results and contributed to the final manuscript.

\section{REFERENCES}

1. D M Nazmul Alam, Khandkar- Siddikur Rahman, Sourav Bagchi Ratu1,Arifa Sharmin, Tania Islam, Md Abu Wabaeid Hasan and Md Nazrul Islam. Properties of Particleboard Manufactured from Commonly Used Bamboo (Bambusa vulgaris) Wastes in Bangladesh. SCIENCEDOMAIN international. 2015;75:203-211.

2. Viện khoa học lâm nghiệp Việt Nam, Nghiên cứu một số yếu tố công nghệ sản xuất ván dăm chất lượng cao làm nguyên liệu cho sản xuất đồ mộc trong điều kiện miền bắc Việt Nam. .

3. Trần Văn Hưng, Nguyễn Tấn Hùng, Nghiên cứu, thiết kế và chế tạo thiết bị phục vụ sản xuất ván ép bột tre, Báo cáo đề tài nghiên cứu khoa học GEN 2016.48.02 02.06, 2016.

4. Nguyễn Thanh Nam, Phương pháp thiết kế phát triển sản phẩm, NXB ĐHQG-HCM, 2014.

5. Nguyễn Như Nam, Trần Thị Thanh (2000), Máy gia công cơ học nông sản - thực phẩm, Nhà xuất bản giáo dục. .

6. Thư viện cơ khí, Chế tạo máy, https://www.pinterest.es/thuvie ncokhi/. 


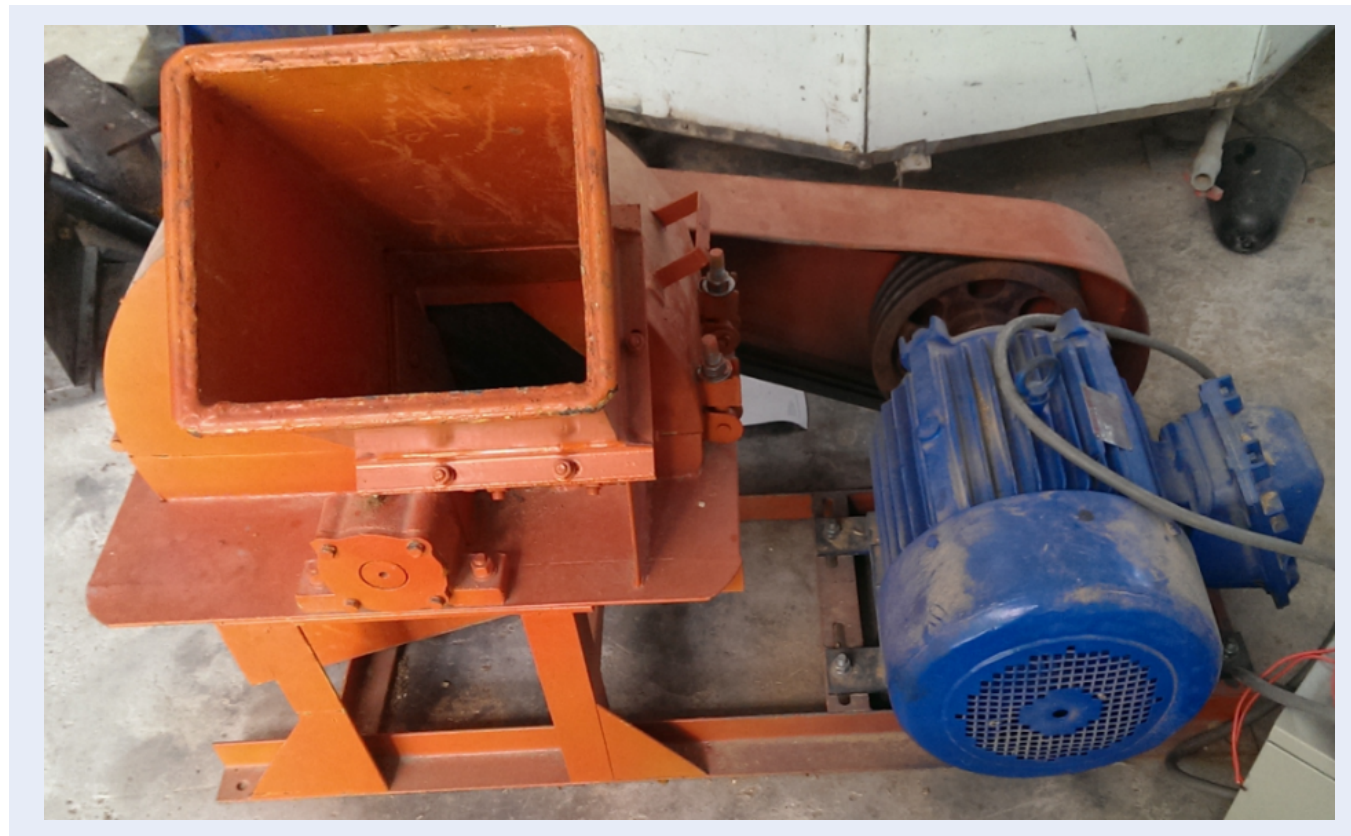

Figure 5: Experimental bamboo grinding machine. 


\section{Nghiên cứu thiết kế máy nghiền bột tre}

\section{Nguyễn Hoàng Hiệp ${ }^{1}$, Võ Tuyển ${ }^{2}$, Lê Khánh Điền ${ }^{1, *}$, Nguyễn Tấn Hùng ${ }^{3}$}

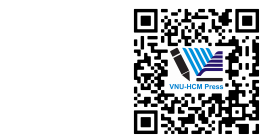

Use your smartphone to scan this QR code and download this article

\section{TÓM TẮT}

Tre là vật liệu bền vững và thân thiện với môi trường, có tiềm năng cải thiện sự suy giảm tài nguyên thiên nhiên. Tre rất phổ biến ở vùng nông thôn của hầu hết các nước Đông Nam Á, đặc biệt là ở Việt Nam. Khả năng của nó có thể thay thế một số loại gỗ trong trang trí và đồ gia dụng. Tre mọc lên nhanh chóng và có thể thu hoạch trong vòng 3 đến 5 năm sau khi trồng, trong khi đơ thời gian thu hoạch của các cây gỗ cứng khác phải từ 8 đến 10 năm hoặc lâu hơn. Các đặc tính vốn có của tre nhẹ hơn các vật liệu gỗ khác và có giá trị về lợi ích xã hội và môi trường. Những tiến bộ của công nghệ sản xuất đã tạo ra các sản phẩm có giá trị cao từ tre như sàn gỗ tre, đồ nội thất tre có thể thay thế cho sàn gỗ và đồ gỗ. Theo các nghiên cứu sinh học, tre có đặc tính có thể thay thế gỗ tự nhiên, nhưng hướng phát triển từ giai đoạn trồng trọt sang giai đoạn thành phẩm chưa được khai thác triệt để. Việc sản xuất ván ép tre sẽ trở thành tiềm năng lớn cho ngành công nghiệp ván ép tre tại Việt Nam. Thông thường, việc chế tạo ván ép tre phụ thuộc vào các quy trình sau đây như cắt nghiển thành bột, quá trình sấy và ép. Trong quá trình cắt và̀ nghiên, phần còn lại của tre sau khi sử dụng có thể được cắt nhỏ và nghiền thành bột được sấy khô và ép thành ván ép tre bằng máy chuyên dụng tương tự như ván dăm gỗ nhân tạo (PB). Mục đích chính của bài báo này là trình bày nội dung công đoạn thiết kế và chế tạo một máy nghiền bột tre vững bền, đáp ứng được các yêu cẩu kỹ thuật và bào vệ môi trường. Máy được chế tạo tại xưởng CAD-CAM của phòng thí nghiệm DCSELab được đánh giá là thỏa mản và đáp ứng được các yêu cầu kỹ thuật của Tập đoàn Làng Tre Phú An.

Từ khoá: Gỗ tre, Bột tre, Máy nghiền
${ }^{1} P T N$ Trọng diểm Điêu khiển số và Kỹ thuật Hệ thống (DCSELAB), Trương ĐH Bách khoa, ĐHQG-HCM, Việt Nam

${ }^{2}$ Trường Đại học Công nghiệp Thực phâm, Việt Nam

${ }^{3}$ Truiờng Cao đảng Kỹ thuật Cao Thắng, Việt Nam

Liên hệ

Lê Khánh Điền, PTN Trọng điểm Điều khiển số và Kỹ thuật Hệ thống (DCSELAB), Trường ĐH Bách khoa, ĐHQG-HCM, Việt Nam

Email: Ikdien@dcselab.edu.vn

Lịch sử

• Ngày nhận: 15-10-2018

- Ngày chấp nhận: 02-1-2019

- Ngày đăng: 31-12-2019

DOI : 10.32508/stdjet.v3iSI1.734

\section{Check for updates}

\section{Bản quyền}

(c) ĐHQG Tp.HCM. Đây là bài báo công bố mở được phát hành theo các điều khoản của the Creative Commons Attribution 4.0 International license.

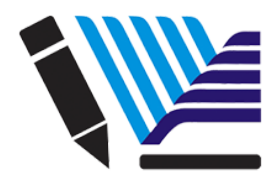

VNU-HCM Press
Trích dẫn bài báo này: Hiệp N H, Tuyển V, Điền L K, Hùng N T. Nghiên cứu thiết kế máy nghiền bột tre. Sci. Tech. Dev. J. - Eng. Tech.; 2(SI1):SI137-SI142. 